\title{
BRAMY RAJU
}

\section{JACQUES RANCIÈRE}

PRZEXOŻYŁ: JĘDRZEJ BRZEZIŃSKI

\begin{abstract}
Abstrakt: Tekst jest rozdziałem wydanej w roku 1981 książki La nuit des proletaires, będącej rozszerzoną wersją rozprawy doktorskiej Jacquesa Rancière’a. Kwestia emancypacji robotników w okresie następującym po porażce rewolucyjnego zrywu w lipcu 1830 roku stanowi centralny problem tekstu. Autor nie komentuje jednak toczonych ówcześnie walk o władzę. Emancypacja ujęta zostaje tu od strony wysiłków podejmowanych na polu estetyki. Estetyczna identyfikacja, ludowe widowiska, oddolna prasa, dobór lektur czy nawet wystrój mieszkania przedstawiane tu są jako pełnoprawne narzędzia emancypacyjnych starań. Rancière pokazuje, że robotnicza kultura, jakkolwiek synkretyczna i pełna zapożyczeń, okazywała się wystarczająco subwersywna, by skutecznie przekraczać klasowe podziały.
\end{abstract}

Słowa kluczowe: proletariat, XIX wiek, francuska kultura robotnicza, emancypacja 
Jedno dzieli się na dwa. Jak jednak rozumieć ten podział dnia i nocy, ów rozłam naznaczający obraz krzepkiego robotnika? Być może tak, jak pewien kronikarz pisma saint-simonistów Le Globe1, który październikowego wieczoru roku 1831 postanowił wmieszać się w tłum mężczyzn i kobiet z ludu, robotnic i czeladników zebranych w sali teatru Funambules². Jeśli pantomima Deburau wydała się dziennikarzowi szczególnie znacząca, to z pewnością dlatego, że była ona rodzajem przedstawienia, jakie lud wystawiał sam przed soba.

Ten człowiek jest ich aktorem, jest sobowtórem ludu - wraz z nim to sam lud wchodzi na scenę, i to lud prawdziwy. Blednie przy nim zbieranina nic nieznaczących statystów w ludowych strojach, którzy mieli tłoczyć się za plecami teatralnych bohaterów. [...] W farsach tego człowieka jest jednak nuta goryczy i smutku. Śmiech, który wywołuje, który tak szczerze dobywa z piersi, okazuje się na koniec raczej bolesny. Ubawiwszy nas setnie na tyle sposobów, ukazawszy całą swą oryginalność i komizm, biedny Deburau, czy raczej - biedny lud! - upada całym swym ciężarem w podległość, uniżoność i służalczość, w których zastaliśmy go na początku sztuki i skąd, poza momentami odgrywanej dla nas komedii, nie wzbił się ani na chwilę. Żegnaj Pierrocie! Żegnaj Gilles! Żegnaj Deburau! Żegnaj ludzie, do jutra! Jutro do nas wrócisz, z tą samą nędzą i tymi samymi wygłupami, tak samo niezdarny, nieporadny, niedouczony, przedmiot kpin bumelantów, których sam karmisz. Oto twoje życie, twój dramat, który nie ustaje nigdy! (Le Globe 1831)

Publicysta dobrze zrozumiał lekcję swojego przywódcy Enfantina ${ }^{3}$ : to w teatrze, tej nowej świątyni ludowych aspiracji, spotkać można lud robotniczy, który żyje swoim własnym życiem. Sekret dwoistości ludu komentator dostrzegł właśnie w jego stosunku do widowisk i w przemianach jego Sobowtóra. Jednak wybór spektaklu i interpretacja, jaką nadaje się prawdzie owej ludowej pantomimy - prawdzie po raz kolejny milczącej - sprowadza początki nowego teatru do nieco starszej metafory. $\mathrm{Na}$ scenie Funambules dziennikarz Le Globe spostrzegł, jak dramat entuzjastycznych dni lipca 1830 roku i ich gorzkich następstw obrócony zostaje w komedię. W porywach i upadkach Deburau dostrzegł on ilustrację głównego wątku saint-simonistycznej propagandy: paryski lud walczył o nic, czy raczej walczył o marzenie, o sprawę, którą dopiero wcielić trzeba w życie. Jednak po swych trzech dniach chwały lud ten popada z powrotem w jeszcze gorszą nędzę. Wydźwignie się z niej

\footnotetext{
${ }^{1}$ Le Globe - dziennik literacko-filozoficzny wydawany od 1824 roku w Paryżu. Od roku 1831 oficjalna gazeta ruchu saint-simonistów. Przestaje istnieć w kwietniu 1832 roku.

2 Paryski teatr, powstały w roku 1816 przy Boulevard de Temple, słynny z występów mima Jean-Gaspard'a Deburau (1796-1846), a zwłaszcza z jego tytułowej roli w spektaklu Pierrot.

${ }^{3}$ Barthélemy Prosper Enfantin (1796-1864) - francuski działacz społeczny, jeden z głównych zwolenników Henriego Saint-Simona.
} 
dopiero, gdy zdoła tchnąć w dzieła pacyfistycznych armii pracy tę chwałę i energię, o której śni wieczorami i którą trwoni w skazanych na porażkę, kilkudniowych zrywach.

Ta opowieść jest jednak czymś więcej niż tylko rozliczeniem z pomysłami na produktywne przekierowanie buntowniczej energii barykad (przykładem takich pomysłów mogłyby być owe „pokojowe rozruchy”, kiedy to każdej pierwszej niedzieli miesiąca strajkujący i żołnierze gwardii narodowej proszeni byli o to, by „zapał i trud, który zużyć mieli czy to na zakłócanie porządku publicznego, czy na jego przywrócenie”, włożyli raczej w prace publiczne; Béranger 1832). Zaprezentowany tutaj obraz ludu idzie dalej niż założenia saint-simonistów. Figura ludu, przedstawianego jako przedmiot zarówno wyzysku, jak i pogardy, ofiara oszustw i ignorancji powiązanych z jego własnym ciężarem jako klasy producentów i żywicieli, w swym podwójnym wizerunku łączy się z obrazem ludu-dziecka, marzenie o swojej własnej emancypacji obracającego w grę, gdy staje w obliczu silniejszych, zaś przed samym sobą - w kpinę; to figura ludu będącego wspólnikiem swego własnego podporządkowania, zapewniającego mu jedynie możliwość wyobrażonych zaprzeczeń i symbolicznych odwróceń: ucieczek do teatru i na goguette ${ }^{4}$, do kilkudniowych insurekcji, których efemeryczne zwycięstwa zdają się odtwarzać dawną funkcję karnawałow i charivari ${ }^{5}$, polegającą na chwilowym odwróceniu ról, niezbędnym do reprodukcji równowagi między dominującymi i zdominowanymi.

W wielu projektach politycznych, zamierzających wyzyskać energię marnowaną w rewoltach i świętach ludowych, a także w licznych obrazach ludowej ignorancji i niekonsekwencji, daje się zauważyć pewną niezmienną cechę wspólną: świadomość proletariatu przedstawiana jest tu zawsze jako zastawiona pomnikami przeszłości i zniekształcona przez terá́niejsze społeczne zapośredniczenia. Klasa robotnicza jest tu stale nieukształtowana i niedokształcona [en formation], naznaczona wciąż jeszcze przez cykliczny rytm właściwy pracom, świętom i „emocjom” ludu wiejskiego; to miejski proletariat, pochwycony przez symboliczną grę, przytrzymującą z iście królewską władzą

4 Goguette - nazwa określająca nieformalne, otwarte stowarzyszenia poetyckie, a także wieczory organizowane przez te stowarzyszenia, w trakcie których śpiewano, recytowano wiersze, dyskutowano, itp. Goguettes były również miejscem mobilizacji politycznej i organizacji samopomocowej. Pierwsza goguette miała miejsce w Paryżu w roku 1729, ich największa popularność przypada na lata 1818-1900, na mniejszą skalę organizowane są do dziś.

5 Charivari - nazwa określająca pochodzący z czternastego wieku, zwyczajowy, okolicznościowy rytuał w formie parady, której członkowie, wyposażeni w bębny, grzechotki, instrumenty improwizowane ze sprzętów domowych itp., robiąc hałas, przechodzą ulicami ulicach miasta bądź pod oknami osoby, „na cześć” której organizowany był rytuał. 
„przedprzemysłowy, wielkomiejski motłoch”; to podstawowa klasa, zepsuta przez iluzje i nauczona nieprzemyślanych form działania, właściwych raczej owym „pośrednikom” drobnomieszczanom, rzemieślnikom i sklepikarzom - którzy szarogęszą się już we wszystkich porach ludowej tkanki; to wreszcie lud robotników, któremu wpoić należy świadomość odpowiadająca jego społecznej pozytywności i formy działania właściwe, by ufundować jego realną emancypację.

To właśnie stąd być może swój początek bierze nieporozumienie między interpretacją aktorów i krytyką teoretyków-widzów. Ich spór dotyczy najpierw sposobu, w jaki rozumie się działanie i definiuje jego oczekiwane efekty: to tu rewolucja lipcowa określona zostaje jako rewolucja po nic. Prawdą jest, że porewolucyjny marazm nawet robotnikom, którym dotąd powodziło się dobrze, przyniósł bezrobocie albo przynajmniej niedostatek zatrudnienia, i że zrujnował wiele inicjatyw i przedsięwzięć. Stan świadomości, w jakim pozostawia on zainteresowanych, nie sprowadza się jednak do goryczy wywołanej zwycięstwem, z którego skorzystała jedynie burżuazja. To raczej świadomość materialnego poświęcenia, będącego ceną rzeczywistych społecznych awansów - tych słono opłaconych szlacheckich tytułów oraz przedsiębiorstw, które wynagrodzić mają kiedyś znój i włożony trud.

W tekstach proletariuszy, którzy żyli podczas karnych lat restauracji, wyraźnie dostrzec można ową sprzeczność między porządkiem zysków ekonomicznych i porządkiem społecznych awansów: „lata, które nastały po restauracji, były dla robotników dotkliwe i trudne do zniesienia" (Voilquin 1978, 68). Na poparcie swego sądu Suzanne Voilquin nie przytacza jednak niczego, co byłoby w stanie zdekonspirować ową ekonomiczną naukę, wykrętnie zapewniająca, że bolesne lata były tak naprawdę korzystne dla przemysłu i pracowników. Jak informuje też jej saint-simonistyczny brat Louis Vinçard, kwitnący interes i rosnące obroty zmusiły jego ojca, producenta przyrządów mierniczych, do zatrudnienia nowych robotników. Relacja Suzanne Voilquin uwidacznia, na czym dokładnie polegała nędza tamtych lat: dla tych, których jedynym zajęciem była praca, czas ten okazał się czasem całkowitej podległości. Autorka wspomina kilka scen: próżną próbę obrony zdradzonego miasta, upokarzająca okupację, żałobny orszak powracających duchów, wreszcie - cudze święta, podczas których okazywało się, że lata przemysłowej koniunktury były czasem upokorzenia pracujących. Także nowo zatrudnionym, a nawet wysoko wykwalifikowanym pracownikom kwitnącego przemysłu bezpieczeństwo ich położenia wcale nie dawało poczucia spełnienia marzeń o społecznym awansie. 
Możemy się tu powołać na przykład Jeana Marchanda, zatrudnionego przez Vinçarda-ojca, który lekceważył wszystko poza tym, „co zdolne jest ćwiczyć i poszerzać intelekt" (Vinçard 1879). Ani produkcja liniałów miarowych, ani nawet dziedziny nauki i przemysłu, do których praca ta dawała dostęp, nie spełniały powyższego kryterium, choć zdaniem postępowej burżuazji były one niemal tożsame $\mathrm{z}$ intelektualną $\mathrm{i}$ materialną emancypacja proletariatu. $\mathrm{Na}$ pewno jednak nie w tym stopniu co gramatyka, której podręczniki Marchand z zapałem przerabia, albo muzyka, której nauczy się sam, by zaraz przejść do studiowania wersyfikacji, do czego nakłoni także syna, któremu zadawać będzie potem ćwiczenia z rymów. Zwieńczeniem tej drogi, gdy Vinçard nauczy się już wyrażać lepiej za pomoca poezji niż prozy, jest właśnie goguette - miejsce, w którym aspiracje zdobycia uznania jako artysta łączą się z „miłością narodowych zasług i publicznych wolności”. To wśród tego nocnego socjalizowania indywidualnych próżności przygotowywane były trzy dni chwały ${ }^{6}$, po których przyszły noce głodu i zimna w latach 1830-1831. To cena uznania robotniczej tożsamości w nowoczesnym społeczeństwie, ale być może także skutek nieumiejętności wykorzystania owych chwilowych awansów i udzielenia odpowiedzi na pytanie o tożsamość, brutalnie dążącą do samopotwierdzenia podczas tych wielkich dni.

\begin{abstract}
Dlaczego - pyta bohaterka Lipca - w tym ponurym labiryncie, w którym błądzimy, jaśniejący obraz owych krótkich chwil jawi się już tylko jako ulotna wizja? Podobni do skazańców w kopalniach, tak jak oni przyzwyczajeni do mroku, nie potrafiliśmy podtrzymać blasku owego tak żywego światła (Fafernot 1833).
\end{abstract}

Metafora ta wyprowadza nas poza obrazy ociężałego ludu-producenta i lekkiego ludufrondysty. Wypowiedź krawcowej Julie Fafernot pozwala dostrzec w upadku Lipca raczej karę, jaką trzeba było ponieść w wyniku porażki tej inicjacyjnej próby. Marsz przez labirynty dnia dzisiejszego i konfrontacja z wczorajszym blaskiem uwidaczniają tożsamość społeczną bardziej skomplikowaną niż to nałożenie się na siebie dwóch obrazów: ludu produktywnego i ludu-dziecka. Na próżno pieśni i manifesty powtarzają refren o tej bazowej klasie, będącej jednocześnie chlebodawcą i cierpiącym rudymentem społecznego ciała. W latach tych zarówno filantropi i utopiści, oświeceni mieszczanie i robotniczy autodydaktycy,

\footnotetext{
${ }^{6}$ Trois Glorieuses - zwyczajowa nazwa rewolucji lipcowej 1830 roku. W przewrocie tym, w ciagu trzech dni jego trwania, zdetronizowano Karola X Burbona, wprowadzono na tron Ludwika Filipa I, potomka linii orleańskiej, młodszej gałęzi dynastii Burbonów, inaugurując tym samym osiemnastoletni okres tzw. monarchii lipcowej.
} 
tradycjonalni, jak i rewolucyjni edukatorzy zgodnie polecali Telemacha7 jako podręcznik dla proletariuszy budzących się do intelektualnego życia. Jakże więc ci ostatni mogli zapoznać lekcję płynąca z reformy zaprowadzonej w królestwie Salente, gdzie rzemieślnicy, których zbyt wielu było w miastach i którzy stanowili „zagrożenie dla obyczajów”, wysyłani byli na tereny wiejskie, gdzie brakowało rąk do pracy? I jak dać wiarę, że ci krawcy, snycerze, odlewnicy, rytownicy, szmuklerze, dekoratorzy i wytwórcy wachlarzy, którzy utrzymywali się jedynie z luksusowej konsumpcji klas uprzywilejowanych, mieliby reprezentować chlebodawczą warstwę społeczeństwa?

Poplątane drogi wiodące do robotniczego miasta, albo ciagłe przeplatanie się wyżyn i dołów każą podejrzewać, że te ludowe przepływy odzwierciedlają coś innego niż tylko wszechstronność „przedprzemysłowego motłochu miejskiego” lub wpływ drobnej burżuazji czy chwiejność tej wiecznie jeszcze „nie w pełni ukształtowanej” klasy. Nieustanna podległość temu kształceniu i kształtowaniu mogłaby być uznana za stałą cechę klasy robotniczej, która na każdym kroku okazywała się jedynie jakimś stadium przejściowym, w którym nawet znawca nie zdoła odróżnić prawdziwego proletariusza od zapóźnionego rzemieślnika lub niewykwalifikowanego przedstawiciela stanu trzeciego. Nie od dziś zresztą szczególnie interesuje nas właśnie owo miejsce przejścia. W punkcie tym synowie chłopów, których rewolucyjny zapał wyprowadził na drogi prowadzące do miast, spotykają się ze sproletaryzowanymi przedstawicielami szlachty, którzy popadli w niełaskę w wyniku tego czy innego wydarzenia politycznego; albo z robotnikami, których asygnacyjna gorączka uczyniła na chwilę przedsiębiorcami, zaraz jednak zmuszeni byli wrócić do swego poprzedniego stanu; czy z wojskowymi, którzy w roku 1815 musieli obrać zapomnianą lub nieznaną im ścieżkę, prowadzącą przez robotnicze warsztaty.

I tak tkacz, syn kupca sukiennego doprowadzonego do ruiny przez własną próżność, która kazała mu na chwilę przed 1789 rokiem kupić sobie tytuł szlachecki, spotyka się tutaj z synem winiarza, mającym szczęście studiować, ale tylko dopóki pech nie doprowadzi jego rodziny do bankructwa, a jego samego nie zmusi do najęcia się jako robotnik w drukarni; albo z owym nastoletnim przędzarzem, synem upadłego właściciela, który dzieciństwo przeżył tylko o kościach przynoszonych z rzeźni i dzięki wyławianiu rtęci z pisuarów; bądź z tym młodym chłopakiem, który został krawcem, ponieważ nauka na tokarza przekraczała 
finansowe możliwości jego rodziców. Tworzą oni niejednorodne i prowizoryczne zgromadzenie niepierworodnych synów, wyruszających w drogę, by dzięki niepewnej pracy swych własnych rąk i nieprzewidywalnej koniunkturze znaleźć źródło utrzymania, a może i dostatku, jakich nie były w stanie zagwarantować im ojczysta ziemia i rodzimy przemysł.

To prawda, że prawne rygory primogenitury, które dziadka tkacza jedwabnego Sebastiena Commissaire' a oraz ojca hafciarki Suzanne Voilquin pozbawiły dóbr, zarezerwowanych w dużych rodzinach tylko dla pierworodnych, zostały zniesione przez rewolucję. Ale nawet jeśli młodsi synowie, będący jednymi z około dwudziestki rodzeństwa, sami nie mają więcej niż dziesięciu potomków, z których zresztą umiera, lekko licząc, połowa, to jednak wciąż nie stać ich, aby wszystkim z nich zapewnić naukę zawodu. Tym bardziej, że ojcowie, jak nieraz sugerują ich dzieci, naznaczeni politycznymi przewrotami epoki, okazuja się bardziej skłonni planować budowę zamków w Hiszpanii, niż inwestować w przyszła pozycję swoich pierworodnych i raczej kręcą się tu i tam, próbując się na szybko wzbogacić, podobni do owych głazów, które nie obrastają mchem, bo ciągle się toczą ${ }^{8}$ Poza ekonomicznymi ograniczeniami i pewnym pomieszaniem wyobrażeń wpływ wywiera tu także rodzinna tradycja i kaprysy uczuć: $z$ ich połączenia dla niepierworodnych wynikaja same nieszczęsne perypetie.

W podobnym położeniu, choć w wyniku odmiennego obrotu spraw, znajdą się tkacz jedwabny nazwiskiem Commissaire i krawiec Troncin: jeden z nich przedwcześnie straci rodzica, rodzic drugiego zaś ponownie się ożeni. Pierworodny syn z drugiego małżeństwa ojca - Sebastian Commissaire - znajdzie się więc w przykrym położeniu intruza. Wkrótce zatrudniony zostanie przez ojca, w jednej osobie tkacza, farbiarza i handlarza, którego nonszalanckie usposobienie nie czyniło wcale obojętnym wobec zasad i spraw autorytetu, dlatego też nie mógł pozwolić, by mówiono, że dzieci z jego drugiego małżeństwa utrzymują się dzięki pracy pierworodnych. Kiedy jednak po okresie chwilowej stabilizacji w Lyonie ten chwiejny ojciec, wiedziony wyobrażeniami fortuny, wraz z jednym ze starszych synów ruszy w pogoń za urojeniami swego serca, wtedy czternastoletni Sebastian obudzi się nagle w roli głowy rodziny, ale i jako uwiązany odtąd na stanowisku tkacza jedwabiu (Commissaire 1888). W przypadku André Troncina, drugiego syna z pierwszego małżeństwa dość obrotnego handlarza drewnem z Besançon, decydująca okaże się antypatyczna macocha. Starszy brat Troncina, przygarnięty przez wuja, otrzyma wykształcenie pozwalające mu

\footnotetext{
${ }^{8}$ Nawiązanie do sentencji Publiliusza Syrusa - Saxum volutum non obducitur musco.
} 
zdobyć „nobliwy status paryskiego handlarza” (Gilland 1850); dla niego samego jednak miejsce znajdzie się jedynie w warsztacie krawca (był to termin dla najuboższych), skąd i on wyruszy do Paryża, po to by zasilić szeregi zawodu o największej liczbie bezrobotnych.

Oczywiście ograniczenia, które jednego z nich zaprowadziły do Paryża, a drugiemu kazały pozostać w Lyonie, mogłyby się jeszcze skomplikować wskutek mniej lub bardziej jawnych decyzji. Stolarz Agricol Perdiguier miał wszelkie możliwości, by pójść w ślady ojca, który zajmował się stolarstwem w Morières. Jego najstarszy, „wykształcony” brat, podobnie jak brat starszy, wolał poświęcić się gospodarstwu i ojcowskiej ziemi. Jednak chłopak, tak jak bracia, nie chciał wcale pracować pod kuratelą ojca tak długo, aż odwrócą się role i sam zostanie jego szefem. Odrzuciwszy również propozycję ciotki, skłonnej pomóc mu urządzić się w Awinionie, także i on pojedzie do Paryża. Wolał chyba, tak jak jego sąsiad, ślusarz Gilland, raczej $z$ dala celebrować cnoty rodzimej ziemi i snuć fantazje na temat ewangelicznego, ojcowskiego, wiejskiego komunizmu, wspominając choćby postać dziadka, który korzystał, jak chciał, z plonów cudzych winnic, uznając jednocześnie prawo, by kto zechce, czynił to samo u niego: bowiem owoce były jego zdaniem jedynie bożą własnością (Perdiguier 1914, 8-9).

W podobnym stylu proletariusz i bajkopisarz Pierre Lachambeaudie rozkoszował się wspomnieniami owych braterskich, urządzanych w wiejskiej szkole uczt, gdzie bogaci i biedni równo dzielili się zawartością swych koszy (Lachambeaudie 1864, 75). Ostatecznie obaj wybrali jednak miejską samotność i zmienną fortunę konkurencji, czyli życie na granicy dwóch światów. Jego ilustrację znajdziemy już choćby w obrazie pokoju, do którego Perdiguier zaprosi Gillanda:

Agricol Perdiguier mieszkał pod numerem 104 na Faubourg Saint-Antoine w paskudnej klitce, zamaskowanej z zewnątrz wystawną fasada cukierni. [...] Niemal wszystko, co otaczało dom Perdiguiera, wzbudzało odrazę i niesmak, kiedy jednak znalazło się w środku, można było poczuć się jak w innym świecie. Posadzka była $\mathrm{w}$ lichym stanie, to prawda; sufit zaś, jak w wiejskich domach, podpierały grubo ciosane, czarne legary. Pokój jednak posiadał niszę przeznaczoną do spania, a ściany pokryte były jasną tapeta, co wywoływało nastrój wręcz radosny. Były tam także dwa okna, a przy nich muślinowe zasłony, przez które prześwitywały owe pnące rośliny, które robotnicy Paryża tak lubili hodować.

$\mathrm{Na}$ umeblowanie składało się wyjątkowo nędzne łóźko, kilka krzeseł, komoda z drewna orzechowego, kwadratowy, masywny stół do pracy i dębowa biblioteczka, 
wypełniona po brzegi całkiem dobrymi książkami. Na kominku stało też oprawne w mahoń lusterko, przymocowane do ściany pozłacanym gwoździkiem, przed nim zaś kragły szklany wazon, w którym sztuczny bukiet kwiatów rozkwitał na jedwabnym mchu. Po obu stronach lustra wisiały urocze poduszeczki z czarnego pluszu, na których upięto, okolone festonami, rodzinny medalion i srebrny zegarek - rodowe klejnoty biedaków. Wszystko to było czyste, lśniące, wypolerowane i ułożone z najwyższą starannością z jaką kobieta, obdarzona smakiem i poczuciem ładu, organizuje to, co ją otacza (Gilland 1851).

To bardzo emblematyczny wystrój. Pnące się rośliny widoczne przez muślinowe zasłony i wyrastający z porcelanowego koszyczka sztuczny bukiet zakwitający pod szklanym kloszem są jednocześnie substytutami rodzimej wsi i pożegnaniem z nią. Między czarnymi belkami stropu i jasną tapetą ścian, między orzechem komody i mahoniową ramą, między nędznym łóźkiem i masywnym stołem, między poduszeczkami i biblioteczką stojące na kominku lustro odbija inną opowieść, ciekawszą niż sam opis źle umeblowanego pokoju stolarza. To raczej historia wzlotów i upadków tej niejednoznacznej postaci, usiłującej przemienić rustykalne ramy swej robotniczej egzystencji, przystrajając je insygniami mieszczańskiej cywilizacji. „Poczucie ładu” i „smak” Lise Perdiguier - zdaniem Gillanda niespotykane poza metropolia - znamionują uspołecznienie innego rodzaju niż pochodzące z wyobrażeń filantropów czy poetyckich tyrad autora $L u d u^{9}$, mimo że ich styl może wydać się podobny. W muślinie zasłon, jedwabnym bukieciku czy radosnym odcieniu tapet dostrzega się dobroczynne wysiłki kobiecej staranności i pragnienia, by na swą skromną miarę wytworzyć w domu i warsztacie robotnika nastrój komfortu. Reakcyjni, choć niewykluczone, że także bardziej przenikliwi komentatorzy rozpoznają tu jedynie wattpliwą pretensję powiązana z niestała pozycją niegdysiejszych chłopów, której nie potrafili umocnić inaczej niż przez zanegowanie swej dawnej tożsamości. Dochodzili w tym zresztą do skrajności, żywiąc na przykład szaloną wiarę, że dzięki oddaniu pracy i przedsiębiorczej odwadze osiagnną poziom życia burżuazji.

Nieszczęście robotniczej kondycji i niebezpieczeństwo, jakie stwarza ona dla ustanowionego przez burżuazję porządku, polega nie tyle na uwolnieniu nędzarzy z ich kajdan, ale raczej na owych ruchach Browna, bez przerwy oddziałujących na ich prekarne i przejściowe sposoby życia. „Musi im się niezgorzej powodzić - zauważa Eugénie Niboyet, złożywszy wizytę w warsztacie szmuklerza Voiniera - w ich niewielkim mieszkanku jest bowiem bardzo przyjemnie" (Fonds Enfantin 1837, Ms. 7815). Jednak przy

\footnotetext{
${ }^{9}$ Jules Michelet (1798-1874), historyk francuski.
} 
nieregularności ich pracy i martwych sezonach, trwających, zależnie od zawodu, od trzech do siedmiu miesięcy, drobna przeciwność losu wystarczała, by zrujnować te kruche aranżacje. W tym przypadku okazała się nią choroba żony Voiniera. By ją leczyć, wykorzystał on najpierw wszystkie oszczędności, następnie musiał rzucić pracę, wkrótce zaś także elementy wystroju ich mieszkania zostały jeden po drugim wyniesione do banku pobożnego (Mont-de-piétê). Bez uwzględnienia tej instytucji trudno zresztą pojąć wieloznaczność robotniczej nędzy: jedni podczas cięższych miesięcy chodzili tam zastawiać biżuterię, pościel lub części posagu; byli jednak i tacy, którzy istnienie tej instytucji wykorzystywali, aby mniejszym kosztem wyposażyć swe początkujące przedsiębiorstwa w niezbędne ruchomości. Tam także drogi początkujących właścicieli mogły się więc przecinać ze ścieżkami prostych proletariuszy.

Dla tych żyjących między dwoma światami ludzi panowanie nie było zresztą pojęciem jednoznacznie pejoratywnym i koniecznie zakładającym chęć przejścia na stronę wyzyskujących. To samo słowo, emancypacja, oznaczać może przecież indywidualny awans robotnika, który się dorobił, równie dobrze jak wyswobodzenie uciskanej klasy. Podobieństwa indywidualnych i kolektywnych ścieżek dają się tu rzeczywiście dostrzec: na przykład w projektach, które mechanik Claude David niestrudzenie prezentuje kapitalistom okresu Restauracji i rządzącym Drugiej Republiki:

Zawsze czułem, że Bóg nie stworzył nas po to, byśmy byli niewolnikami naszych braci i czyniłem, co w mojej mocy, by wyzwolić się z ucisku, jaki dusił proletariacką biedotę. [...] Miałem lat dwadzieścia trzy, toteż czułem się na siłach, by się z niego wyswobodzić, skoro poczułem, że ciężar, który kazano mi nieść, nazbyt jest ciężki. [...] Wynalazłem podówczas nowy rodzaj krosna, dzięki któremu byłem w stanie wytwarzać wyśmienite tkaniny do produkcji chust. Na okres stawiania maszyn zatrudniłem też współpracownika. Był to młody chłopak, który cierpiał jak ja i, podobnie jak ja, bardzo pragnął się wyzwolić [s'émanciper]. [...] Zdaliśmy sobie sprawę, że bóle, któreśmy cierpieli, były także bólami naszych braci; ja osobiście z radością wyobrażałem sobie, że być może będę w stanie wyzwolić [émanciper] jeszcze kilku z nich (David 1848, 63 64).

Nawet wśród najbardziej rewolucyjnych robotników trudno znaleźć takich, którzy ani przez moment nie marzyli o przyszłości pracodawcy; niejednemu z nich zresztą się to udało. 
Sam ideał robotniczej organizacji nie wykluczał się z burżuazyjną nauką Poczciiwego Ryszarda10. Świadczy o tym choćby kuriozalna inicjatywa powołana w najgorszym momencie roku 1848 przez czterech robotników, zajmujących się produkcją prawideł i ogólnie znanych ze swych „anarchistycznych” poglądów:

Pewnego dnia spotkali się we czterech. Warsztaty narodowe, ostatni ratunek przed głodem, podówczas już nie istniały.

Co robić? Łączna wartość ich aktywów wynosiła dwa franki. [...]

Cóż można zdziałać, mając dwa franki? - spytałby milioner, który dwa franki wydaje po sto razy dziennie.

Oto co można zrobić:

Kupić kawał drewna.

Następnie?

Obrobić go, wycinając zeń pewną liczbę prawideł; te sprzedać.

Następnie?

Kupić dwa kawały drewna; w międzyczasie jeść mało albo wcale; obrabiać dalej.

W końcu?

Założyć największy dom handlowy w tej branży, który zrzeszy koło siedemdziesięciu rzemieślników i osiagnie obroty 80000 franków rocznie (Jay 1851).

Socjalistyczne marzenia nie wykluczają się tu wcale z cnotami przedsiębiorcy. To one jednak próżnymi czynią ojcowskie pouczenia, zapewniające dobrych robotników tych czasów o tym, że czeka ich tak samo szczęśliwy los jak ten, który czekał skromnych pracowników z lat dwudziestych dziewiętnastego wieku, cieszących się dziś, dzięki swym wysiłkom, całkiem niezłym dostatkiem jako właściciele manufaktur. Nasi dobrzy robotnicy także nie czekali długo, by pójść w ślady swych poprzedników i poświęcić swoje niewielkie zarobki na rzecz przedsiębiorstwa, które wkrótce miało wybawić ich od kondycji proletariuszy. Szybko jednak zrozumieli, że fronty walki klas nie całkiem pokrywają się z linią podziału na pracodawców i robotników. Ci, którzy wczoraj ponaglali ich, by zabrali się do pracy i zaczęli się dorabiać, dziś raczej bez zadowolenia obserwuja, jak ci drudzy wzięli ich rady na serio i włączyli się do konkurencji.

10 Poor Richard's Almanack - popularny almanach wydawany przez Benjamina Franklina w latach 1732-1758. 
Bez wątpienia liczne porażki owych chwilowych pracodawców wynikały z błędu ich podstawowych założeń: z nierozpoznania faktu, że bycie zręcznym pracownikiem nie wystarczy, by przeniknąć tajemnicę kosztów przychodu i umieć ocenić wypłacalność klientów. Ale wiedza nie gwarantuje sukcesu w większym stopniu niż ciężka praca i uczciwość. Mimo że nauka „armatora-kancelisty” Pierre’a Josepha Proudhona ujawniła swoje „wstrząsające efekty” (Proudhon 1875 t. II, 10), rujnując konkurentów jego szefa, okazuje się ona zupełnie bezużyteczna, gdy „zmęczony niepewną kondycją i nędzą robotniczego życia" wraz z jednym ze współtowarzyszy postanawia on założyć drukarnię: „Szczupłe zarobki dwóch przyjaciół i całe oszczędności ich rodzin zostały rzucone na koło rulety. Perfidna gra interesów zawiodła nasze nadzieje: porządek, praca, oszczędność wszystko na darmo" (Proudhon 1875 t. I, 30). Poza nieprzewidywalnymi obrotami przemysłowej ruletki pracownicy, niezależnie od wykonywanego zawodu, zaczęli dostrzegać teraz groźbę ataku także ze strony tego przeciwnika bez twarzy, który na swą ofiarę może czaić się wszędzie: „błądzącego kapitału, bez określonego celu i bez profesji”, jak określa go w roku 1848 grupa zjednoczonych robotników ebenistów i ich pracodawców (Petycja ebenistów, A.N., F 12/4636).

W tych warunkach dochodziło częstokroć do zrównania lub odwrócenia pozycji pana i robotnika, co wywoływało jakby efekt metyzacji. W ten sposób komentuje to jedne z saintsimonistycznych emisariuszy:

W dzielnicy tej żyje ogromna liczba ludzi, będących kimś pomiędzy pracodawca a pracownikiem. Mówiąc dokładniej, są oni po trosze i tym, i tym - zatrudniani są bowiem przez pracodawców i traktowani przez nich jak robotnicy, a jednocześnie sami zatrudniają i przez swych pracowników traktowani są jak pracodawcy. A ponieważ nawzajem znają się tu wszyscy i dzielnica ta składa się częściowo właśnie z tych politycznych mieszańców (polityka zresztą w wysokim stopniu ich zajmuje), byłoby dobrze, gdyby nasza gazeta dotarła także do nich, aby mogli się zapoznać i z nasza polityką Fonds Enfantin 1837, Ms. 7816).

Emisariusze różnorakich doktryn będą stykać się z ową „metyzacją” częściej niż tylko wśród robotników-pracodawców z dziewiątej dzielnicy Paryża. I to ona właśnie skłoni do poszukiwań, na politycznej scenie, tożsamości, która nie miała szansy się wytworzyć wzdłuż chwiejnej linii podziału między pracodawcami i salariatem. Nie wynika stąd jednak wcale, że chwiejną musiała być sama ta tożsamość. To prawda, że wśród krawców wszyscy mistrzowie byli kiedyś robotnikami. Ale właśnie dlatego ich robotnicy uważali za słuszne, 
by wymagać od swych mistrzów takiego samego traktowania, jak traktowali oni innych przedstawicieli burżuazji. Jeśli krawieccy czeladnicy, ubiegając się o pracę, musieli włożyć surdut, wydawało im się właściwe, aby także mistrz zdejmował kapelusz, wchodząc do warsztatu. Ta równość w porządku wyglądów i konwenansów wyraża nową paradoksalna godność, którą robotnik czerpie z uczestnictwa w ryzyku i zmiennych losach prowadzenia przedsiębiorstwa.

Prekarność pracy, zagrożonej nie tylko przez kaprysy wyniosłych, zamożnych konsumentów, ale także spekulacje błądzącego kapitału, nadaje nową formę robotniczej godności, ustanowionej przez wymuszony mariaż wolności robotnika i wolności pracodawcy. To już nie dawny, wsparty na regułach czeladnictwa podział między czasem mistrzów i czasem robotników; to raczej wywalczony udział w nieregularnych przychodach przedsiębiorstwa, w którym na dawne hierarchie, zależne od różnicy wkładu i wydatków, nakładaja się nowe uzasadnienia zysku. Pozostająca wciąż w gestii prywatnej [domestique] relacja łącząca wolnego czeladnika i przedstawiciela burżuazji, który go potrzebuje, zmierza do punktu, gdzie zastępuje ją wyobrażona hierarchia, w której uznanie okazuje się zależne w większej mierze od poniesionego ryzyka niż posiadanych kompetencji. Pozycja godna szacunku jest tu określana poprzez stosunek do odrazy wzbudzanej przez tych, którzy są w tej hierarchii jeszcze niżej: dziecko w liberii zasypywane sarkastycznymi komentarzami przez czeladników z sąsiedniego warsztatu; dorosły najmujący się na służbę, co do którego strajkujący robotnicy zarzekają się, iż nie chcieliby nim być za nic w świecie.

Hierarchie te wspieraja się rzecz jasna na pewnych obiektywnych podstawach: służącymi zostaja przecież dzieci rodziców, których nie stać na opłacenie im żadnego terminu, nawet w warsztacie krawieckim, wysyłają je więc na osiem, dziewięć lat służby, by zdobyły w ten sposób jakieś pieniądze - a przynajmniej oszczędziły im wydatków. Tę hierarchię sankcjonuje jednak także pewien radykalizm wyborów: służący to ci, którzy w wieku lat około piętnastu przestraszyli się losu robotnika, bo „widzieli tylko jego złą stronę: okropną nędzę”. Ten strach przed nędzą pieczętuje ich własny los: życie, w którym czas nie podlega podziałowi, zamknięte w animalnej sferze potrzeb - ich własnych, ale także ich panów.

Wszystko więc już wiadomo, ich los to służba aż do momentu, kiedy awansowani zostaną na zarządców, czyli, jak to się mówi, dobrze sytuowanych, i kiedy dysponując niewielkim majątkiem, będą mogli wrócić w rodzinne strony i dokonać żywota, 
w którym nie było miejsca na chwałę ani podstaw do tego, by móc choćby pretendować do czegoś więcej niż życie (Bertaut 1841).

Do czego innego jednak - poza śmiercia - pretendować można w życiu? Krawcowi Bertaut, który z równą pogardą wymawia słowa służyć i żyć, nie potrzeba filozoficznych pouczeń na temat związku podległości z lękiem przed śmiercią. Taka genealogia służebnego poddaństwa nie odsyła już do funkcji pana, ale do tej trzeciej pozycji, chcącej wyzwolić się z więzi: do niezależności. Słowo to oznaczało ideał dla tych, którzy zawieszeni byli między zwierzchnictwem i podległością, gdzie konflikt tych stron lub wyższość jednej nad druga zależał nie od kompetencji, ale od wyboru prekarności i od wiedzy, czy raczej pseudo-wiedzy o swym cierpieniu. Podczas krótkiego okresu, jak mówi Bertaut, kiedy mógł „uczęszczać na nauki”, czy to w szkole Tour de France, czy w szkole miejskiej, robotnik odbierał „połowiczne wykształcenie” pozwalające mu „dzięki lekturze codziennej prasy oraz wszelkich broszur publikowanych w celu informowania ludu, zorientować się w tym, co dzieje się w społeczeństwie, zrozumieć, że jemu także przysługuja prawa; to przewaga okupiona wysoką ceną i dużą ilością ciężkich westchnień”.

Przewaga westchnienia! Istotnie, pracownik warsztatu krawieckiego nie może pochwalić się niczym więcej z tego, co decydować miało o wyższości pracy najemnej nad służbą: wprawnym ruchem ręki czy niedającymi się zastąpić kwalifikacjami, będącymi powodem dumy robotników i kompromisów ich pracodawców. Paradoks jest następujący: ludzi, którzy mogliby wykonywać najprostszą pracę służących, nigdy nie ma dosyć; tymczasem wykwalifikowanych robotników, nieważne jak bardzo wysokie byłyby ich kwalifikacje, zawsze jest zbyt wielu. „Ogromna rozkosz” ogarniająca dwudziestoletniego typografa na widok kaszty zecerskiej („Mam fach, mogę iść wszędzie, nie potrzebuję nikogo” - mówi on do siebie; Proudhon 1868 t. II, 348) znajduje ripostę w cynicznej lekcji, jakiej udziela saint-simoniście drukarz z Globe. Przypomina mu on, że w obecnej przemysłowej anarchii jego kwalifikacje znaczą tyle, co los na loterii:

Jako że znalazłem się w sytuacji bez zatrudnienia, Ojciec Chevalier napisał do pana Everat, że pragnąłby, aby znaleziono dla mnie miejsce w Le Globe. P. Everat, którego spotkałem w salonie, obiecał, że wkrótce mnie tam wprowadzi, tym chętniej, że nie był ostatnio zadowolony z pracy kilku zatrudnianych zecerów. Nie chciał jednak nikogo wydalać w sposób gwałtowny ani nieregulaminowy. To podejście podobało mi się; ostatecznie wszystko jednak potoczyło się inaczej. W końcu p. Everat napisał do mnie, abym przyszedł i zajął miejsce jednego z zecerów. Zakładałem, że chodzi o wakat - 
wcale jednak tak nie było. Wziął mnie za rękę i poprowadził do biura, następnie zaczął wypytywać pracujących tam drukarzy, jak się nazywają, a ich nazwiska zapisywać na karteczkach, które następnie włożył do kapelusza i rzekł: „Panowie, ten, którego nazwisko pierwsze wypadnie z kapelusza, zostanie wydalony, a jego miejsce zajmie p. Mallard. Jeśli zaś komuś metoda ta się nie podoba, także może odejść" (Fonds Enfantin, Ms. 7757).

Towarzysze krawca Bertauta okazuja się jeszcze mniej podatni na iluzje godnej pracy niż drukarze z opowieści Mallarda. Krawców spotkać można było wszędzie, w warsztatach, w mansardach, w portierniach i na paryskim bruku. Byli nie do zliczenia: w roku 1848 ich liczba osiagnęła 22500 według statystyk Izby Handlowej; według Pierre’ a Vinçarda 40000 (Vinçard 1849). Trudno też rozstrzygnąć, którzy z nich byli najbardziej godni pożałowania: krawieccy czeladnicy, stłoczeni w warsztacie jeden przy drugim, siedzący na ziemi, z nogami skrzyżowanymi i plecami zgarbionymi nad zawsze zbyt wąskim blatem, czy też krojczy wyrobnicy [apiéceurs] w ich mansardach, usiłujący zachęcić klientów detalicznych do swych wyrobów, które tak tanio sprzedają kontrahentom. Jakby nie było, krawcy byli pracownikami, których najłatwiej było zastapić. Potwierdzają to wszyscy: żaden cech nie jest bardziej wrażliwy, żaden bardziej nie troszczy się o należne mu względy, ani nie jest bardziej gotów, by wciagnąć w rewoltę tłumy robotników.

Pozowali oni na pierwszych obrońców robotniczej godności, ale godność ta nie miała nic wspólnego z dumą z wykonywanego zawodu. Duma ta okazuje się przy tym raczej czynnikiem rozłamu w robotniczym świecie, a nawet pretekstem do walki na śmierć i życie. W latach pięćdziesiątych znajdowano wciąż zwłoki szewców, ofiar nienawiści podsycanej powszechnie wśród czeladników przez przedstawicieli królewskiego fachu stolarzy, przeciw temu ordynarnemu i nieładnie pachnącemu zawodowi, uzurpującemu sobie godność rzemiosła. Wrażliwości owych krawców nie można jednak także utożsamić z arystokratycznym oburzeniem, z jakim do dyrektora teatru Gaîté przyjdzie grupa grawerów [ciseleurs], rozgoryczonych wystawieniem sztuki, która przedstawia ich w nędznych, roboczych ubraniach:

Czy Pańscy aktorzy nie widzieli na oczy grawerów? Czy nie wiedza, że jest to zawód luksusowy? W waszej sztuce obleczono nas w stroje ostatnich pajaców. Niechże więc aktorzy będą uprzejmi je zmienić, albo przyjdziemy ich wygwizdać! Niechże się panowie dowiedza, że nie jesteśmy ani murarzami, ani dekarzami, a to do nich pasowałyby kostiumy, jakie noszą wasi aktorzy (L'Artisan 1851, 48). 
Przedrukowany w prasie robotniczej list grawerów spotkał się z ogólnym potępieniem. Mówiąc dokładniej, wrzawa przeciw tej fałszywie pojętej koncepcji robotniczego honoru dała się słyszeć najgłośniej właśnie w prasie krawców i drukarzy. Sami murarze na przykład nie odpowiedzą na list wcale $-z$ trzech powodów, sprowadzających się do jednego, jeśli wierzyć temu, co pisze Pierre Vinçard: po pierwsze, murarze nie czytali gazet, po drugie, nie chodzili do teatru, po trzecie, nie przywiązywali oni żadnej wagi do kwestii swego ubioru. Wszystko to było kosztowne i odwodziło od drogi, którą jego zdaniem wybierali murarze, nie rozglądając się na boki; drogi, która od wykształcenia i pracy w murarstwie prowadzić miała do zasadniczego celu: zakupu ziemi gdzieś w kraju. Murarz, człowiek, którego cała inteligencja nakierowana jest na doskonalenie się w swym fachu, który zaskakuje zleceniodawcę łatwością, z jaką odczytuje najbardziej skomplikowane plany sporządzane przez ludzi sztuki, nie sytuuje się przez to wcale na szczycie, ale przeciwnie - na samym dole w hierarchii robotniczej godności; najbliżej granicy oddzielającej robotników od służących, do których upodabnia ich gospodarska fiksacja i zmysł oszczędności. Czy to właśnie dlatego wewnątrz ich profesji natychmiast odtworzone zostają wewnętrzne napięcia charakterystyczne dla służby domowej - konflikty tych, którzy znają tylko dwie relacje społeczne: służyć i rozkazywać?

\begin{abstract}
Smutną jest rzeczą widzieć tych ludzi, których nie łączy nic poza praca i niebezpieczeństwem [...], niepołączonych żadnymi innymi stosunkami ponad te, które wiążą służącego z jego panem [...]. Jednocześnie przyszłość robotnika to największa ambicja młodego pomocnika, patrzy on zazdrosnym okiem na najemników i zazdrości uznania, jakie zdobywa czeladnik. Umysł jego i siły koncentrują się wyłącznie na tym celu. Kiedy mistrz na chwilę się oddala, porzuca on kastrę $\mathrm{i}$ wbiega szybko na górę, chwyta kielnię $\mathrm{i}$ z zapałem bierze się do murowania. Indolencja jego nagle przekształca się w gorączkową aktywność, pragnienie kierowania i przynęta lepszych zarobków sprawiają zaś, że szybko zaznajamia się z narzędziami. Po kilku lekcjach odbytych w ten sposób osiaga zazwyczaj status robotnika. Zdarza się jednak, że gdy go już osiagnnie, okaże się, na wzór starożytnych wyzwoleńców, bardziej bezlitosny, niż inni byli wobec niego (Vinçard 1851, 48).
\end{abstract}

Taki obraz murarzy naszkicowany przez dawnego złotnika łączy się ze sposobem, w jaki opisywał służących pewien krawiec-pieśniarz z La Ruche populaire ${ }^{11}$. Hierarchia stojąca za tym

\footnotetext{
${ }^{11}$ La Ruche populaire - gazeta ruchu robotniczego we Francji, wydawana w Paryżu od 1839 roku.
} 
obrazem nie wynika z różnicy kwalifikacji czy jakości ubioru, ale z wrażliwości na spektakle, które tych chłopskich robotników pozostawiały obojętnymi: cuda niedostępne dla ich wytwórców, wyłożone na wystawach jubilerów, marszandów mebli i brązowników; piękna aranżacja i bogaty ornament miejskich pomników, wodewilowe śmiechy i melodramatyczne płacze, teatralne i polityczne namiętności. Słowem wszystko to, co pozwoliłoby robotnikom wyjść poza dopełniające się sfery warsztatu i domu, wykroczyć poza pole konfliktów ze zwierzchnikami i wziąć głębszy oddech w tej trudnej do zdefiniowania, coraz cięższej i zwodniczej atmosferze: opinii publicznej.

To pole, w którym formuje się, na przekór burżuazyjnej próżności grawerów i gminnej chciwości murarzy, robotnicza godność charakterystyczna dla krawców, przybyłych do stolicy w poszukiwaniu odpłaty za nędzę, pecha i niesprawiedliwość - czyli wszystko to, co był w stanie obiecać im ich marny fach. Czy to strategiczna lokalizacja ich warsztatów, ich wynajmowanych pokoi i mansard między ulicą Chaussée-d'Antin zamieszkiwana przez królującą burżuazję i Tuileriami należącymi do burżuazyjnej monarchii, daje im dzielony z drukarzami przywilej bycia pierwszym diapazonem opinii publicznej? A może to raczej fakt, że przemysł modowy i fabryki opinii publicznej pozostawały w bezpośredniej bliskości i w obu wytwarzano atrybuty społecznej dystynkcji?

Niewątpliwie stąd też brały się szczególne roszczenia, dające wyraz ich radykalizmu. Dwudziestego października 1833 roku najbardziej progresywna z republikańskich gazet, Le Bon Sens poinformuje na przykład, nie bez pewnej nuty szyderstwa, o niesamowitym wzroście konsumpcji tytoniu wśród „eleganckiej młodzieży”. Kilka dni później jednak poczuje się w obowiązku donieść także o strajku robotników z zakładów krawieckich, domagających się prawa do palenia w pracowniach. Krawcy nie mają się wszak za „elegantów”, a jeśli zdarza im się czasem wystroić, to głównie wtedy, gdy idą dorabiać jako klakierzy w teatrze. Pismo La Fashion w swoisty sposób demonstruje logikę, zgodnie z którą roszczenia i walki klasy pracującej zaczynają obejmować także kwestię decorum:

\footnotetext{
Murarz, stolarz, malarz czy ślusarz w swej codziennej pracy nie potrzebują luksusowej garderoby: płócienne spodnie, bluza i czapka to wszystko, na co muszą sie wykosztować. Krawiec również nie potrzebuje eleganckiego ubrania. A jednak nie obejdzie się on bez płaszcza lub surduta, porządnego obuwia i kapelusza, bo gdyby przyszedł do mistrza w swej zwykłej kamizelce i czapce, nie wpuszczono by go nawet do środka. Mając więc tak duże koszta, a przy tym dużo niższe zarobki i szanse na stałe zatrudnienie, nie jest on wcale szczęśliwy. Jest to zrozumiałe. Najprostszy sposób
} 
wyjścia z tej przykrej kondycji to zacząć zarabiać więcej. Tak zaczyna zawiązywać się koalicja przeciw przełożonym (La Fashion déc. 1841).

Na początku analizy krawiecki mistrz i autor artykułu Augustin Canneva podejmuje klasyczny argument burżuazji i filantropów, według których dobre prowadzenie się robotników ma być jedynym sposobem rozwiązania kwestii społecznej. Jednak w miarę kolejnych publikacji na łamach wydawanej przez niego gazety w analizie tej dokonuje się pewne przemieszczenie. Augustin Canneva nie jest tylko jednym z tych krawców, którzy zostali mistrzami dzięki oddaniu swej pracy, ale należy także do bocznej linii mistrzów, którym nie wystarcza samo robienie interesów: będa oni chcieli do swoich zakładów wprowadzić nauki matematyczne i społeczne. Tak jak krawiecki mistrz Barde, przyjaciel saint-simonistów i fourierystów, albo proletariusz i saint-simonista Delas, wynalazca pewnej maszyny mierniczej, czy Suireau, zażarty republikanin i jeden z dwóch przywódców strajku roku 1840, Canneva jest jednym z pionierów „cięcia geometrycznego”, którzy ściagnęli tym samym na siebie falę sarkazmu ze strony „prawdziwych” krawców, rozgniewanych fanfaronadą „profesorów cięcia”, tych „papierowych krojczych” - jak mówili - bogatszych w adeptów niż w klientów (Couannon 1852).

On także poszukuje jednak wyjścia z kryzysu, który przeciwstawia mistrzów i robotników już nie sobie nawzajem, ale wspólnemu przeznaczeniu zawodu, zagrożonego tym, że w ciagu ośmiu lub dziesięciu lat zostanie on „podany na tacy kapitalistom” ( $L a$ Fashion 20 août 1842). W toku wydatków i roszczeń każe nam dostrzec nie tyle efekt kiepskiej konduity młodych krojczych, ale raczej błędne koło, wynikające z samej istoty ich zawodu, zależnego od mody i zagrożonego ze strony kapitalistycznej racjonalności konfekcyjnego przemysłu.

Bez wattpienia, przyznaje Canneva, młodzi krawcy nie są racjonalni - czy jednak nie to właśnie jest cechą młodych ludzi? I któż jeśli nie oni mógłby przyzwyczaić się do zawodu, który z rytmu codziennego życia wykrawa pięć bezczynnych miesięcy rocznie, a w sezonie zmusza do pracy w godzinach niedających się pogodzić z życiem rodzinnym? Zawód ten w mniejszym stopniu jest dziś zagrożony przez gorączkowość młodzików, którzy w ciagu siedmiu miesięcy zarobić chcą tyle, by przyjemnie przetrwać pozostałe pięć, niż przez tych dobrych mężów i ojców, którzy, by wykarmić swoich najbliższych, za śmieszne pieniądze najmuja się podczas martwych sezonów fabrykantom konfekcjonowanej odzieży, 
zalewającym rynek odzieżą w ilościach hurtowych, gdy tylko ruszą na nowo krawieckie warsztaty.

Także Canneva szukać będzie wyjścia z kryzysu właśnie w porozumieniu zawartym przeciw wspólnemu wrogowi między pracownikami i mistrzami krawieckimi, które przekształciłoby się w coś na kształt sądu pracy [organisation paritaire des prud'hommes]. W roku 1848 także inni przedsiębiorcy dostrzega w stowarzyszeniu pracodawców i pracowników jedyną możliwość ochrony ich zawodu w sytuacji, kiedy presja rynku zredukowała kierownictwo do samej iluzji władzy. Zapytuje pewien przedsiębiorca z Bordeaux we wstępie do opracowanego przez siebie projektu:

Kim jest więc właściciel przedsiębiorstwa w zindywidualizowanym przemyśle? Czyż jest on dziś czymś więcej niż tylko śliskim zboczem dzielącym producenta i konsumenta? Czymś innym niż koleiną toczoną co dzień przez przesuwający się po niej metal? Co pozostaje mu poza uciskiem ze strony silniejszych i zależnością słabszych od niego? (Duluc, A.N., F 12/4631)

Ale to właśnie podział tego, co pozostaje, stanie się zarzewiem konfliktu i robotniczych strajków, w których paryscy strajkujący nawoływać będą do solidarności, a w podwójnym roszczeniu sformułowanym $\mathrm{w}$ trzecim punkcie ich programu $\mathrm{z}$ roku 1833 sformułuja propozycję parytetu: „postulujemy wprowadzenie stosunków opartych na niezależności i równości z pracodawcami”. W tej ogólnej formule kryją się trzy konkretne roszczenia: domagają się oni pozwolenia na palenie tytoniu, przerwy na czytanie prasy a także tego, aby szef, wchodząc do warsztatu, miał obowiązek zdjęcia kapelusza. To stąd być może wzięła się słynna w roku 1848 przyśpiewka: Chapeau bas devant ma casquette!12. Jednak ta pantomima, na którą wielu się zresztą nabierze, posiadała być może pewną funkcję - podkreślając niemal królewską wyższość wytwórców, zaklinać miała to, co najbardziej niepokojące w owej dziwnej formule „niezależności i równości z pracodawcami”. Istotnie, wezwanie do niezależności od tych, od których jest się zależnym, to niemądry zakład robotnika, zwłaszcza takiego, którego najłatwiej zastapić. Te głupie zakłady va banque na krótszą metę okażą się największym niebezpieczeństwem. Nie zemszczą się oni na szefach przez sabotaż pracy; ci zaś, choć skarżą się na sposób, w jaki robotnicy się prowadzą, na ogół chwalą dokładność ich pracy. Nawet higieniści wskazywać będą na wzajemne powiązanie tych dwóch

\footnotetext{
12 Cytowana przez Flauberta w Szkole učuć: „Zdjąć kapelusze, hej! przed czapką / Przed robociarzem na kolana!" (Flaubert 1985).
} 
spraw i na szkodliwe skutki posłuszeństwa, które zmusza robotników do spędzania wielu godzin w pozycji siedzącej, ściśniętych jeden obok drugiego, tak że w natłoku pracy zapominają nawet o „przerwach na jedzenie i sen” (Decoux 1835, 15).

\begin{abstract}
Wszędzie, gdzie tłoczą się ludzie bezczynni, czyli tacy, których mięśnie nie podejmuja żadnego wysiłku i których umysł nie ma żadnego pożytecznego zajęcia, wyobraźnia wyprowadzona zostaje na niebezpieczne ścieżki. A jako że krawcy także pozostaja stłoczeni w jednym miejscu, również i oni skazani są na niemal pełną bezczynność (Monneret 1838, 190).
\end{abstract}

Osławione „złe prowadzenie” nie było jednak jeszcze najniebezpieczniejszym ze skutków tego rozmycia się granicy między pracą a odpoczynkiem, a także dyskusji, piosenek i snów na jawie, które się doń przyczyniały. To raczej wątpliwa próżność, wynikająca przy tym wcale nie z robotniczej świadomości partnerstwa i własnych zręczności, wiedzy oraz wprawnego oglądu, ale przeciwnie - z poczucia, że jest się w nadmiarze. Równie dobry był ich wybór przywódcy wielkich strajków z 1833 i 1840 roku, przywódcy, którego osobowość wyraża tu najlepiej społeczne i wyobrażeniowe stawki ich walki. Mowa o wspomnianym już André Troncinie, który urodził się - tak jak Victor Hugo - w roku 1802 w Besançon, a przez zazdrość macochy skazany został na czeladnictwo w warsztacie krawieckim i wyruszył do Paryża, by rozwijać „dystyngowany, czysty i wymagający, wielkomiejski gust” (Gilland 28 nov. 1850). André Troncin, jak donosi Gilland, „nie pogardzał władza, jaką egzekwowała burżuazja, ale nienawidził jej jako kasty". Ona zresztą darzyła go podobnie mieszanymi uczuciami. Podczas gdy kasta rządzących raz po raz wsadzała go do więzienia, poszczególni zatrudniający go przedsiębiorcy zapewniali mu zarobki w wysokości od 2000 do 2400 franków rocznie i chętnie zlecali mu kierownictwo w warsztatach, widząc jak dużym cieszy się posłuchem. W ostatnim z więzień, z którego rządzący burżuazyjnej kasty nie pozwolą mu wyjść aż do śmierci, zażyczy sobie jeszcze od żony, by wysłała mu „ilustrowaną Ewangelię, którą [dostał] w podarunku od właściciela po tych dwóch tygodniach, kiedy to się tak [narobił] przy jego wielkim zamówieniu" (Gilland 12 déc. 1850).

Ten uprzywilejowany stosunek zapewnia mu z pewnością lepszą pozycję w walce o uznanie niż pozycja licznych anonimowych pracowników, których jedyną bronią w tej walce była gotowość do ryzykowania; był też w najlepszej pozycji, by przewodzić zbiorowa walką jednostek, których nie łączyła żadna z więzi stanowiących o sile innych cechów: 


\begin{abstract}
Robotnicy z innych cechów rozumieją się między sobą lepiej. [...] Czeladnicy pomagaja sobie wzajemnie w podróżach. Załatwiają jedni drugim materiały, pożyczki i zlecenia, i wzajemnie się umoralniają. Inaczej wśród krawców - tu niepodzielnie panuje pożałowania godny egoizm. Nie zawiązuje się tu żadna więź braterska. Dzień dobry na powitanie, dobrego wieczoru - na pożegnanie, to wszystko, co maja sobie do powiedzenia (La Fashion 20 avr. 1842).
\end{abstract}

Należałoby wszakże dodać, że jedność tych zaledwie mijających się robotników, którzy u jednego mistrza nie zagrzewali miejsca dłużej niż trzy miesiące, formowała się wyłącznie w opozycji do innego: burżuazji, której egoistyczny sposób życia będą starali się imitować, u których, założywszy surdut, będą się meldować, i od których domagać się będą takiego kodeksu, w którym prawo do strajku uznane zostanie za równoważne wobec prawa do zwalniania. „Nie oddawajmy naszych rąk aroganckim właścicielom, póki nie wyznaja swoich win! Bądźmy też jednak sprawiedliwi, pozwalając im odprawić tych, którzy już im nie odpowiadaja”" (Grignon 1833, 4). Nowe strajki, których pionierami byli cytowani indywidualiści, nie mogły dłużej dawać sygnału do powrotu na Awentyn, jak dawniej miało to miejsce w przypadku potępianych czeladników. Jednak ich przewaga wynikała z tego, że wywierali wpływ na wroga poprzez określanie ryzyka i kosztów. Uczucie „bycia nadmiarowym" to jednocześnie impuls roszczeń wnoszonych przez tych, których godność bierze się z ryzyka nędzy, ale także impuls zbiorowej rewolty przeciw sytuacji, która czyni z każdego robotnika jednostkę nadmiarową, sprzeciwu wobec konkurencji nadmiarowych rąk do pracy.

Gra kosztów jest więc czymś bardziej skomplikowanym, niż zaświadczają o tym komunały filantropów, którzy za nieprzemyślane wydatki robotników spragnionych przyjemności obwiniają nędzę, a także czymś bardziej złożonym, niż widzą to ci, którzy naga nędzę i powagę walki oddzielają od odurzających fantazmatów, albo - na odwrót - dziki przepych ludowych orgii przeciwstawiają służebnej lub walczącej moralności pracowitej mrówki. Mimo że skontrastowana z beztroską niemoralnością hulaszczych robotników, moralność oddanych robotniczych działaczy stawia sobie za punkt honoru to samo, co tamta: odrzucenie oszczędności ma tu świadczyć o społecznej wyższości robotniczego stylu życia nad kondycją służby. Dowodem tego są choćby nieustające kazania moralistów z L'Atelier przeciw działalności i ideologii kas oszczędnościowych. Bardziej jeszcze symptomatyczna wydaje się łatwość, z jaką dwa zasadnicze argumenty zlewają się tu ze sobą. Pierwszy z nich denuncjuje tę próbę - ma na celu przerobienie robotników na egoistów i skorumpowanie ich 
zdolności do solidarnego działania. Drugi orzeka, że ubogie warunki życia robotników nie pozwalają im na oszczędzanie. Oszczędzają służący, ale nie robotnicy - stwierdzenia tego nie sfalsyfikowałyby nawet statystyki, pokazujące rosnący procent oszczędności odkładanych przez robotników, mimo ich początkowej nieufności. Odmowa ta ma status filozoficznego a priori i jest kryterium ich społecznej godności.

Odmowa oszczędzania nie określa więc tylko abstrakcyjnego zrównania beztroski prekariusza i sumienności apostoła. Ma ona także posłużyć za maksymę nowego rodzaju uznania, która robotnicze walki i sojusze z poziomu partykularyzmu oddzielnych profesji i panowania materialnych sił podnieść miała do rangi uniwersalności, zapewniającej robotnikowi prawo do uczestnictwa w nowej dystrybucji. Chodzi o to, by wykroczyć poza atomizację, sprawiająca, że „nie istnieje coś takiego jak klasa, są tylko jednostki” (Leroux 1833, 11), nie narzucając jednak stowarzyszonym całej serii ograniczeń, jednoznacznych z powrotem pod jarzmo kastowej władzy i zatraceniem cechowych swobód. Broń, która była narzędziem ich walki ze zwierzchnikami, okazała się też narzędziem ich poróżnienia, a siła użyta w ich ekonomicznych zmaganiach jednocześnie przyczyniła się do pogorszenia ich społecznego statusu: „Brak szacunku do siebie nawzajem, nieustanna wojna i mordercze współzawodnictwo między robotnikami sprawiły, że utracili oni wiele ze swej społecznej pozycji, wolności i dobrobytu" (Perdiguier 1914, 234). Odzyskanie tego statusu wymaga zawiązania jakościowo nowej solidarności: nie tylko jako odzyskanej władzy w relacjach ze zwierzchnikami, zmuszonymi do uznania ich praw, ale jako wymiaru nowej uniwersalności, zapewniającej im uznanie i ustanawiającej nowe społeczne stosunki, które zagwarantowałyby im miejsce w królestwie rozumu i cywilizacji.

Tego rodzaju godność wymaga jednak zerwania z tymi, którzy status swój zdobyć chcą dzięki fizycznym wysiłkom i zręczności. Dyskurs uprawiany przez L'Atelier w imieniu klasy robotniczej dotyczy tak naprawdę półrobotników, niedorównujących stolarzom sprawnością ani znajomościa geometrii, ubranych dużo gorzej niż grawerzy; robotników nieprawdziwych, jak powiedzą nawet ci, którzy odwiedzili pewną drukarnię, gdzie „kierownikiem był dawny adwokat, [...] korektor [l’homme de conscience] studiował wcześniej medycynę, a wśród składaczy był także profesor, dawny chirurg okrętowy, który dziesięć lat przeżył z plemieniem Indian oraz Hiszpan, emerytowany kapitan z armii Don Miguela" (Décembre i Alonnier 1862, 70). Obraz ten jest z pewnością trochę podkolorowany: dawni drukarze i autorzy tego opisu chcieli z pewnością dorównać klasycznym przedstawieniom 
barwnych fizjognomii, w których świat drukarzy przedstawiany był jako „zajazd”, gdzie schronienie znajdowały ,zapomniane profesje, zgubione cele, utracone pozycje i zawiedzione nadzieje" (Ladimir 1840 t. I, 266). A jednak sami zainteresowani musieli mieć świadomość, że w hierarchii tej zajmuja niskie miejsce nowicjuszy. Trzydzieści lat później redaktor naczelny $L$ 'Atelier nawiąże do kwestii tytułowania:

Także i nasza gazeta L'Atelier miała pewien wkład w uświadomienie pracownikom, do których się zwracała, że również krawiec z igłą w ręku i drukarz, ustawiający w szpaltach małe, ołowiane literki zasługują na tytuł robotnika, zupełnie tak jak piekarz, snycerz czy farbiarz (Leneveux, 166).

To zabranie głosu w imieniu klasy robotniczej poprzedza jednak wewnętrzna rewolucja i wywrócenie hierarchii sił i sprawności. Hierarchie te, wspierające się ostatecznie na przypadkowych okolicznościach urodzenia albo na arbitralności społecznych dystynkcji, odtwarzają ostatecznie w głębi robotniczego świata kastowy system prawny, który sankcjonuje pozycje podporządkowanych. Stąd uprzywilejowana pozycja owej dziwnej awangardy operatorów igieł i małych ołowianych czcionek: robotników pozbawionych mocy, ale także złudzeń co do swych kwalifikacji (naśmiewali się oni przy tym z pomysłu założenia „drukarni dla kobiet”. Na próżno jednak udają znawców praw konkurencji - nawet jeśli liczba piśmiennych kobiet nie była wówczas wysoka, wystarczyłoby ich, by zastapić wszystkich drukarzy); robotników ryzyka i tymczasowości, których znaczenie zależało od ich frontalnej pozycji: zawsze najbliżej burżuazji, dostarczając szat jej dystynkcji i materialnej oprawy dla produktów jej myśli; zależnych od tych przewrotów na górze, których zstępująca władza zapośredniczona była przez prasę i modę. W pewnym sensie byli oni sami już prawie burżuazja - w najlepszej pozycji, by przejąć jej język i ubiór, podkreślając jednocześnie to, co ich różni, jak odcień ekscentryczności czy niedbałość w toalecie, kpina artysty mieszająca się z kiepskim gustem parweniusza: „Coś, co psuje, co drażni, co zgrzyta, co niszczy harmonię, razi w oczy i nawet spod lwiego futra zdradzi robotnika" (Ladimir 1840 t. I, 271); najlepiej sytuowani zwłaszcza po temu, żeby rewaluować dążenie do zwierzchnictwa i panowania, będące integralną częścią zawsze przejściowej kondycji robotnika i skonfrontować je z nowymi warunkami klasowej dominacji i rządów kapitału. Dzięki pomocy księgowych i sklepikarzy, którym L'Atelier przyznaje prawo do mówienia w imieniu robotników, formułuje się dyskurs ich klasy; prawo, którego odmawia pracownikom wzbogacającym się dzięki pracy innych. Prawo to zyskuje szczególną funkcję: 
robotnikowi dochodzącemu do bariery oznaczającej początek panowania zwierzchników lub pracownikowi fizycznemu, który pada ofiarą arystokratycznych uprzedzeń, L'Atelier proponuje nowy ideał, gdzie niemożliwość wykroczenia poza wyznaczoną im pozycję przerobiona zostaje na konstruktywną odmowę: odrzucenie służby, którą delektują się chwilowi pracodawcy i którą egzekwują brygadziści, subiekci i księgowi; zastępcze domaganie się pozycji społecznej, którą zdobywa się w walce o „równość” z przełożonymi; klasowy ideał całkowitego niemal upodobnienia do burżuazji, by lepiej jeszcze zaznaczyć to, co ich odróżnia, i podkreślić swoją odmowę oraz równościową aspirację. By zdobyć obywatelstwo burżuazyjnej cywilizacji, należałoby więc, z jednej strony, pozacierać znaki szczególne właściwe klasie robotniczej, które odsyłały do naturalności systemu kastowego i panowania siły. Z drugiej strony, należałoby też zdemaskować w ich własnych odruchach burżuazyjne stygmaty egoizmu i wyzysku. Walka o uznanie zakłada ten podwójny ruch: przejście od feudalnej władzy siły do burżuazyjnej władzy rozumu, ale i rzucenie arystokratycznego wyzwania mieszczańskim normom oszczędności i bogacenia się.

Chodzi tu więc o marzenie o stanie równowagi, gdzie prywatne kaprysy burżuazyjnej fortuny albo arystokratycznej godności dadzą się pogodzić z definicją pewnej tożsamości zbiorowej. Jej przykładem może być historia przywróconego do pracy młodego drukarza, którego odurzył zrazu przepych królewskiego miasta (,pragnął najmodniejszych strojów, perfumowanej pościeli, pierścieni z brylantami [...], w roli swych kompanów widział zaś zawsze młodzież ze sfer nieco wyższych niż jego własne”; Gilland 13 févr. 1851). Wkrótce jednak „widok oddania i licznych poświęceń”, jakich dokonywali jego towarzysze walki, otwiera przed nim „horyzont nowego życia” i jego pociąg do zbytku zastępuje potrzeba uczestnictwa, obok innych robotników, w walce na rzecz demokracji.

Ta zmiana jednak staje się także regułą nowej hierarchii: 18 grudnia 1831 roku na zebraniu robotników saint-simonistów przed zgromadzeniem zaprezentował się tapicer Julien Gallé, mianowany uprzednio na propagandzistę w jednym z czterech sektorów Paryża. Młodzieniec, w którego zachowaniu styl mieszczanina mieszał się ze stylem robotnika, poinformował zgromadzenie o podwójnym poświęceniu, jakiego postanowił dokonać w ramach swego apostolatu: odtąd oddawać będzie saint-simonistycznej rodzinie swoje skromne oszczędności i zrezygnuje z oferowanego mu stanowiska pierwszego subiekta, predestynującego go do roli następcy właściciela. Jego ton nie zdradza jednak wyrzeczenia, ale wdzięczność: 
Narodzony z rodziców proletariuszy, dochodząc w handlu do najwyższego stopnia, jaki dzięki swym zdolnościom osiagnąć mógł proletariusz, nigdy nie zdołałbym jednak przekroczyć tej społecznej bariery, oddzielającej mnie od tych, którzy urodzili się uprzywilejowani. Byłem zrozpaczony, wy jednak zaprosiliście mnie i daliście mi nadzieje (Le Globe 23 déc. 1831).

Nie jest jednak wina Juliena Gallé, że ostatecznie skończy jako kapitalista i filantrop. To raczej kapłani nowego życia opuścili jego; musiał więc znów wziąć się do roboty, by „odzyskać reputacje niestrudzonego pracownika”, która „nieco podupadła” (Fonds Enfantin 1833, Ms. 7728).

Jednak kilka dekad komercyjnych sukcesów i społecznych prac nie wystarczy, by zatrzeć wspomnienie tej ulotnej chwili i wyjątkowego marzenia o odnalezieniu pełni, poszukiwanej w trakcie wieczornych goguettes dopełniających dni pracy, w trzydniowych rewolucjach wybuchających raz na piętnaście lat upokorzeń, w zawodowych sukcesach mimo goryczy robót; marzenia o uprzywilejowanym punkcie równowagi między prekarnością „niezależnej” pracy a nowymi zależnościami, w które natychmiast popadali ci, którzy choćby tylko wznieśli się ponad jej poziom; marzenia o niepodzielonym czasie, bez martwych sezonów, gdzie dostarczana usługa - poza służalczością i ciagłą koniecznością „sprzedawania się” - znajduje dodatkowe wynagrodzenie w poczuciu, że samemu jest się swoim kierownikiem. Ścieżki jednostkowych przygód przecinaja tu wyobrażony plan szczególnej, wspólnej przyszłości: cywilizacji mieszczańskiej bez wyzysku, rycerstwa bez dominacji, mistrzostwa bez podziału na panów i podległych, czyli jednym słowem: robotniczej emancypacji. 


\section{Wykaz literatury}

Béranger, Charles. 1832. „L'Émeute”. Le Travail 9 juin.

Bertaut. A. 1841. „Au Peuple”. La Ruche populaire févr.

Canneva, Augustin. 1838. Livre du tailleur, guide complet du tracé, de la coupe et de la facson des vetêments. Suivi de l'Hygiene du tailleur par M. Monneret. Paris: Pagnerre.

Commissaire, Sébastien. 1888. Mémoires et Souvenirs. Lyon: Meton.

Couannon. 1852. Le Parfait Tailleur. Paris.

Couannon. 1837, 1838. Journal des Merchands Tailleurs juill. 1837, janv. 1838.

David, Claude. 1848. Organisation du travail, Moyen d'obtenir pour chaque travailleur, à l'âge de 55 ans, une pension de mille francs par an. Paris.

Décembre, Joseph i Edmond Alonnier. 1862. Typographes et gens de lettres. Paris: Plein Chant.

Decoux, Alexandre. 1835. Jean-Jacques compris par les tailleurs ou Bonbeur de tout ce qui peut condre, aidé par la philanthropie. Paris.

Deluc. Projet d'association des tailleurs de Bordeaux. A.N., F 12/4631.

Fanfernot, Julie. 1833. L'Étincelle. Paris: Prospectus.

Fonds Enfantin, Ms.: 7815, 7816, 7728, 7757.

Gilland, Jérôme-Pierre. 1850. „Biographie des hommes obscurs. André Troncin”. La Fenille du village 28 nov.

Gilland, Jérôme-Pierre. 1851. „Biographie des hommes illustres. Agricol Perdiguier”. La Fenille du village 3 avr.

Gilland, Jérôme-Pierre. 1850. „Biographie des hommes obscurs. André Troncin”. La Feuille du village 12 déc. 1850.

Gilland, Jérôme-Pierre. 1851. „Biographie des hommes obscurs. Adolphe Boyer”. La Feuille du village 13 févr. 1851.

Grignon. 1833. Réflexions d'un ouvrier tailleur sur la misère des ouvriers en général la durée des journées de travail, le taux des salaires, les parrorts actuellement établis entre les ouvriers et les maitres d'ateliers, sur la nécessité des associations d'ouvriers, comme moyen d'améliorer leur condition. Paris.

Jay, Emile. 1851. „Visite aux associations”. Le Bien-Être universel 3 août.

L'Artisan oct. 1842.

La Fashion 20 avr. 1842.

La Fashion 20 août 1842.

La Fashion déc. 1841.

Lachambeaudie, Pierre. 1864. „Le déjeuner à l'école”. W Cent fables. Paris: Pagnerre.

Ladimir, Jules. 1840. „Le compositeur typographe”. W Les Français peints par eux-męmes. Paris: Curmer.

Leneveux, Henri-Charles. Le Travail manuel en France. Paris: G. Baillière.

Leroux, Jules. 1833. Aux ouvriers typographes. De la nécessité de fonder une association ayant pour but de rendre les ouvriers propriétaires des instruments de travail. Paris: L.E. Herhan.

Perdiguier, Agricol. 1914. Mémoires d'un compagnon. Paris.

Petycja ebenistón. A.N., F 12/4636. 
Proudhon, Pierre-Joseph. 1858. De la Justice dans la Révolution et dans et dans l'Église. Paris: Garnier.

Proudhon, Pierre-Joseph. 1875. Correspondance. T. I-II. Paris: Lacroix.

„Spectacles populaires”. 1831. Le Globe 28 oct.

Voilquin, Suzanne. 1978. Souvenirs d'une fille du peuple. Paris: F. Maspéro.

Vinçard, Jules. 1879. Mémoires épisodiques d'un vieux chansonnier saint-simonien. Paris: E. Dentu.

Vinçard, Pierre. 1849. „Les ouvriers tailleurs”. Le travail affranchi 7 janv.

Vinçard, Pierre. 1851. Les Ouvriers de Paris. Paris: Gosselin. 
Jacques Rancière - francuski filozof, emerytowany profesor uniwersytetu Paris VIII SaintDenis. Jeden z najszerzej komentowanych obecnie myślicieli. Jego pierwszą publikacją była napisana wspólnie z innymi naukowcami (pod kierunkiem Louisa Althussera) praca Cyytanie „Kapitału”, która dokonała ważnego przełomu w recepcji myśli marksistowskiej. Poza tym jest autorem: Le maître ignorant: Cinq leçons sur l'émancipation intellectuelle (1987), Na bræegach politycznego (1990, pl. 2009), La mésentente: politique et philosophie (1995), La chair des mots: politique de l'écriture (1998), Dzielenie postrzegalnego (2000, pl. 2007), Malaise dans l'esthétique (2004). Rancière jest uważany za jednego z najciekawszych współczesnych filozofów zajmujących się zarówno filozofia polityki, jak i teoretycznymi oraz historycznymi kontekstami sztuki.

CYTOWANIE: Rancière, Jacques. 2017. „Bramy raju.” Praktyka Teoretyczna 1(23): 132-159.

DOI: $10.14746 /$ prt.2017.1.5

AUTHOR: Jacques Rancière

TITLE: Gate of Heaven

ABSTRACT: The text presented here is a chapter from Jacques Rancière' s La nuit des proletaires, an extended version of the author's doctoral thesis. It focuses upon prospects for workers emancipation following the unsuccessful revolutionary attempt of July 1830. Rancière does not comment on struggles of power and instead, emancipation is seen here mostly as an intervention into the aesthetic. Aesthetic identification, popular spectacles, grassroots press, the selection of readings and even the design of rooms are all presented as genuine tools of the emancipatory effort. Rancière shows that workers culture, although syncretic and full of calque, turned out to be subversive enough so as to undermine class divisions.

KEYWORDS: proletariat, nineteenth century, French workers' culture, emancipation 